\title{
Application of the Principles of Business Judgment in the Authoritative Function of Directors of Limited Liability Company in Singaporean and Indonesian Legal Perspectives
}

\author{
Daniel Hendrawan ${ }^{1}$ \\ Emilia Fitriana Dewi ${ }^{2}$ \\ Subiakto Sukarno ${ }^{2}$ \\ Isti Raafaldini Mirzanti ${ }^{3}$ \\ ${ }^{1}$ Universitas Kristen Maranatha, \\ Bandung, Indonesia \\ ${ }^{2}$ Universitas Padjajaran, Indonesia \\ ${ }^{3}$ School of Business and Management, \\ Institut Teknologi Bandung, Indonesia
}

Doi: 10.36941/ajis-2020-0044

\section{Abstract}

The purpose of this study is to analyze the functions and authority of the director of limited liability company in applying business judgment principles, by taking comparative law studies in Singapore's common law and in Indonesia's civil law. By taking emphasis on the authority of directors in representing limited companies both in and out, there are several authorities that are regulated in it. This study was conducted with a comparative law approach, with descriptive qualitative analysis. The results showed that sometimes directors act outside their authority and can harm a limited liability company. On the other hand, that there are actions of the board of directors that are in accordance with their authority but still harm the limited liability company. In this case, the shareholders often hold accountable. In corporate law there is a principle of business judgment where a director cannot be held accountable if the directors are proven to have good faith. The difference between Singapore law and Indonesian law in regulating the authority of directors is the good faith assessment held by directors.

Keywords: business judgment rule, good faith, directors, Limited Liability Company, Singapore, Indonesia

\section{Introduction}

The dominance of the company does not only occur in Indonesia, but also in the United States and other countries. The occurrence of such conditions is because the company is believed to be able to become a means for fertilizing capital which is greater when compared to other business entities. This Limited Liability Company is a fairly developed business in Indonesia. This right can be seen from the development of the number of limited liability companies in Indonesia and also has many advantages over other business entities that are not incorporated. The reason the company is in great demand is also because of its distinctive characteristics, where the company is a capital association in 
the form of an independent legal entity, which provides limited liability to its shareholders. Limitation to its shareholders is that the shareholders' responsibility is limited to shares owned in the limited liability company. Thus, the shareholders do not need to have any concern that their personal wealth will be absorbed into every tax plan made by the company.

The term Limited Liability Company consists of two words, namely company and limited. The Company refers to the Limited Liability Company capital consisting of shares. The word limited refers to the responsibility of shareholders whose extent is only limited to the nominal value of all shares held by them. So in a limited liability company has limitations on liability. This limitation of responsibility is interpreted when being held accountable to third parties. Accountability to third parties is limited only to the amount of capital that is included in a limited liability company. As a legal entity, a limited liability company that carries out business activities has certain purposes and objectives. Therefore, business activities carried out by limited liability companies are carried out in the context of realizing the aims and objectives of establishing a limited liability company. Limited liability companies are not permitted to carry out activities other than the intent and purpose of a limited liability company. The purpose and objectives are given to limit the limited liability company in conducting business activities and guarantee legal certainty for what is done in a limited liability company.

In a limited liability company there are corporate organs that carry out daily corporate activities. According to Law No. 40 of 2007 concerning Limited Liability Companies, limited liability companies have three organs, namely the General Meeting of Shareholders, Directors, and the Board of Commissioners. The General Meeting of Shareholders is a gathering place for shareholders to vote in relation to limited liability companies. The Board of Directors has the authority to regulate the problems of the company's activities every day, so here the authority of the directors to carry out and regulate the activities of the limited liability company both with other parties and inwardly. The board of commissioners is authorized to supervise the performance of directors in limited companies. In daily activities, the board of directors of a limited liability company may also have errors or omissions caused by inadvertence. These errors can be intentional errors or unintentional errors. These unintentional errors can also cause losses to a limited liability company, but in good faith limited liability company directors become difficult to prove the element of error made by the company's directors. Managers in business entities are also not much different from those contained in limited liability companies.

The Board of Directors has the authority to carry out the management of the company in accordance with policies that are deemed appropriate within the limits specified in the Limited Liability Company Law and/or articles of association. What is meant by "policies that are deemed appropriate" are policies, which, among others, are based on expertise, available opportunities, and prevalence in similar business worlds. This policy often has an unclear meaning because in this policy there is no standard measure. The existing size is a good intention of the directors' actions so that it does not harm the limited liability company. The basic concept of Business Judgment Rule comes from US Common Law (case law) and has been further developed in the past 30 years through court decisions, especially the Delaware Supreme Court, and codified in The 2001 Australian Corporation Act. Business judgment rule is an estimate or assumption in making business decisions that do not use or include personal gain or personal problems, the company directors in exercising their authority as directors of the company, in good faith and honesty that what they do is for the best interests or benefits for the company.

The principle of Business Judgment Rule is actually based on the common law legal system, so in this paper the author intends to compare the principles of the Business Judgment Rule in Indonesia with the countries that adhere to the common law legal system, namely Singapore. Singapore has quite a contiguous area that can even be said to be next to each other and has a fairly high economic level so that it has a fairly good role in the application of the Business Judgment Rule principles. In Law No. 40 of 2007 concerning Limited Liability Companies regulated on the issue of business judgment rule, it is necessary to understand more deeply the good faith of a company 
director who applies this principle in his actions to make the best decisions for the company. This is a problem if there is a loss in the company due to his decision, the inspection has been in good faith and in accordance with his authority, but it turns out that it still harms the company.

In Article 97 Paragraph (5) of Law No. 40 of 2007 concerning Limited Liability Company, the members of the Board of Directors cannot be liable for losses if they can prove where there is a loss that is not due to error or negligence, even though it has managed in good faith and prudence and in accordance with the purposes and objectives of the Company, which results in losses and has taken action to prevent such losses from arising or continuing.

The Board of Directors is required to take full responsibility for the management of the company for the interests and objectives of the company, and to represent the company, both inside and outside the court. The Board of Directors in good faith and full responsibility must carry out duties for the interests and business of the company. The Board of Directors can be sued personally to a district court if the company suffers a loss caused by its mistakes and negligence. Likewise, in the case of bankruptcy in the event of a director's error or negligence and the company's assets are insufficient to cover losses due to bankruptcy, each member of the board of directors is jointly and severally responsible for the loss.

\section{Limited Liability Company in Legal Perspective}

Understanding Company Limited Company Limited in Dutch called Naamloze Vennotschap (NV) means the company without a name, which is nameless individuals who enter the actual company taken from the French language, called Societe Anonyme (SA).

In addition, a limited liability company can also be interpreted as a shareholder association created by law and applied as an 'artificial person' by an court, which is a legal entity which is therefore completely separate from the people who set it up by having the capacity to continue to exist and as a legal entity, a limited liability company has the authority to receive, hold and transfer assets, sue or be sued and carry out other authorities given by applicable law (Fuady, 2003). This pseudo-human is also taken from a theory of legal entities in which legal entities are false and do not have a real form or form so that they have organs to carry out daily tasks in a limited liability company.

According to the author, limited liability is a company that has similarities with partnerships but here the difference is regarding shares. Limited liability companies have capital that is divided into shares where the owners of capital or shareholders have limited responsibility for the company, which is only limited to shares owned, so that accountability to third parties is only limited to pay up shares as capital in a limited liability company.

\section{Authority and Responsibility of Directors in Indonesia}

According to Article 1 number (5) Law No. 40 of 2007 concerning Limited Liability Company directors is explained as an authorized organ of the Company and is responsible for the management of the Company in the interests of the Company, in accordance with the purposes and objectives of the Company, both inside and outside court in accordance with the provisions of the articles of association.

The Board of Directors which is basically a body executive branch $f$ or managers of companies or implementing business activities so that the company can realize its goals and objectives have obligations and responsibilities with a broad scope, and in carrying out the obligations that the Board of Directors to uphold the principle of fiduciaries duties which essentially Directors hold any creed management for the benefit of the company (Fuady, 2003).

As a company manager, the Board of Directors has two main obligations to the company, namely Duty of Care and Duty of Loyalty. The first obligation emphasizes a minimum standard of attention and wisdom. Duty of care determines assessment standards for the adequacy of corporate 
decisions. The second obligation emphasizes the alignment of the company when the Board of Directors is the holder trust (fiduciary) the company carries out a transaction contrary to the interests of the company (Solomon \& Palmiter, 1999).

The responsibility of the board of directors of a Limited Liability Company is to carry out the management of a Limited Liability Company for the benefit of a Limited Liability Company and according to the purposes and objectives of a Limited Liability Company, then the delegation of the management of the interests of the Limited Liability Company to the board of directors is based on the trust relationship (fiduciary) between the Limited Liability Company and the board of directors. This relationship is called a fiduciary relation or relationship of trust which subsequently gave birth to the directors' fiduciary duty of Limited Liability Companies (Widjaja, 2004).

The implementation of the Board of Directors' obligations as a corporate organ that is fully responsible for the routine management of the company is complemented by the authority stipulated in Law No. 4 of 2007 concerning Limited Liability Companies. This is basically in line with the view that the Board of Directors needs authority to be able to fulfill its obligations and carry out its functions (Gibson, 2003).

\section{Business Judgment Rule}

Besides the fiduciary duty conception, especially the duty of care and skill/diligence, in the conception of the Business Judgment Rule, The member of the Board of Directors is not easily deemed to have committed a violation of the duty of care and skill, as long as he has taken an action based on good faith, except if there is fraud, conflict of interest, or illegal acts (illegality) (Widjaya, 2004; Shubhan, 2020).). The concept of the Business Judgment Rule, which originated in the United States, prevents courts in the US from questioning business decision-making by the Board of Directors, which is taken in good faith, without personal interests, and can be held accountable for making a favorable decision company (see for instance, Stout, 20o1; Hinsey IV, 1983).

Therefore, it is appropriate if a company director is not generalized to be responsible for his mistakes in making decisions (error of judgment) without consideration of his human element (Widiyono, 2009). Business judgment doctrine traditionally refers to rule in concept to protect the interests of members of the Board of Directors from liability to the decision of certain businesses resulting in losses for the company (Widjaya, 2004). According to Wilamarta (2007). This Business Judgment Rules doctrine is the only defense that can be used by directors who have good intentions in protecting themselves from claims by Limited Liability Companies, shareholders, and/or creditors of Limited Liability Companies in connection with losses due to wrong decisions taken by the Directors. Business Doctrine Rule Judgment is a reflection of the independence and wisdom of the Directors in making business decisions. Khairandy and Latif (2009) revealed that if the directors' actions that cause losses are not based on good faith, then they could be categorized as fiduciary duty violations, which give birth to personal responsibility.

\section{Business Judgment Rule According to the Singapore Company Law}

In Vita Health Laboratories Pte Ltd E Ors v Pang Seng Meng [2004] 4 SLR (R) 162, it is stated that incompetence is not ipso facto is considered a fiduciary duty violation even though it may attract other leaders as a liability (see, Tan, 2004; Pinsler, 2004; Agrawal, 2017). A director who by act or does not act causes harm to the company is very possible the action is questioned (Mohd-Sulaiman, 20o9). Without evidence of lack of bona fides, this cannot be justified if it is argued that directors are always responsible for their failure in business assessments for all losses suffered by the company. The duties of the Board of Directors are in good faith originating from a fiduciary relationship directors must be with the company, the main characteristic of which must act in good faith/bona fide in the best interests of the company. Fiduciary duty of a director has some purposes. First, bonafide and for the benefit of the company (see, Sealy, 1989; Langford, 2011). A director must act bona fide for what he 
considers to be the best interests of the company and not for the purpose of personal gain. This is a subjective test. As long as the directors' motives are honest, and can show that they are fulfilled in their own minds that actions are beneficial to the company or true, directors are usually immune from the process that they must act in different ways or, by looking back, more decisions good maybe.

Second, power for the right purpose: A director must exercise his power for the benefit of the company and only for the purpose or purpose they are given, even if he believes that to do otherwise will be in the best interests of the company. The Board of Directors will exceed his authority if he carries out daily activities for improper purposes.

Third, conflict of interest: A director does not have to put himself in a position where there is actual or potential conflict between his duties for the company and his personal interests. To avoid the possibility of liabilities having actual or potential conflicts to arise, directors must ensure that the conflict is disclosed to, and approved by, the company. An area where conflicts of interest often arise is the entry of transactions between companies and directors.

According to article 157 paragraph (2), an employee of a company is not permitted to make improper use of any information obtained based on his position, to obtain, directly or indirectly, profit for himself or for someone else or cause harm for the company, so that he is guilty of committing a crime and is charged by the company for profit and loss suffered and also criminal responsibility. A director of a company that buys or sells company securities while he is in possession of information in the case of an insider-dealing company-violating article 218 of the Securities and Futures Act, Chapter 289 of Singapore (SFA) (see, Tjio, 2016; Loke, 2005). Likewise, a director who gets another person to buy or sell company securities while he has inside information commits a violation under the SFA. Violation of the duty of a good faith director can lead to criminal or civil liability (Article 157 (3). In certain circumstances, the court can also make a cancellation order as a director. The procedure is to resign from the board of directors of the listed company immediately after he is disqualified from acting as director in a jurisdiction for reasons other than technical reasons. Some arrangements regarding good faith in chapter 16 of the company act in Singapore meant that directors must act in good faith due to the absence of regulations regarding the Business Judgment Rules in legislation in Singapore.

In Duty at Common Law to Act for Proper Purposes, company management is generally held by the board of directors and the board will often have other more specific powers such as the power to issue shares according to article 161 of the Act, provided the directors have obtained a special or general mandate to do so. This power must be carried out for the right purpose. Even if directors have acted in good faith in what they believe is in the best interests of the company, they may have carried out certain powers in an improper way. For example, it has been argued that, where the power to issue shares is used to facilitate takeover bids for a company, it is not an appropriate exercise of power as although directors feel that they act in the company's best interests - see the Howard Smith Ltd v. Ampol Petroleum Ltd case [1974] AC 821 (see, Goddard, 2008; Sealy, 1992; Smart, 2000).

In Statutory Derivative Action, Section 216A (2) of the Act that prosecutor maybe applies to court for leave to bring action on behalf of and on behalf of company or internal interference action that company is party for the purpose of sue, defend or stop action on behalf of the company (see, Choo, 2001). Court will only give leave if the court satisfied in section 216A (3) Law the claimant has given 14 days' notice to company directors from intention to file leave; reporter Act in good faith; and seems to be prima facie for the benefit of company that action brought, prosecuted, defended or terminated. One of profit from action derivative law is the authority of the court ordered the company to pay reasonable legal fees and expenditure, which is issued by the claimant in connection with action. In action derivative general law, risk legal fees fall on the person who reports. 


\section{Conclusion}

ASEAN has a vision to transform the region of Southeast Asia into a stable, prosperous and competitive region supported by a balanced economic development, poverty reduction and socioeconomic disparities between Member States. However, laws relating to cooperatives in ASEAN are still minimal. Since the differences between historical law among ASEAN especially in Singapore and Indonesia, so it cannot be moderate the law. In ASEAN Economy Community, there are several business case that involving two or more countries, therefore the business judgement rule should refer to the agreement based on the ASEAN agreement. The good faith in running the company doing by the Directors is one of the important values that will conduct the business smoothly, therefore the directors in company in each country should have a the same perspective that agreed upon same meaning eventhough each countries have a different basic law. Comparison of the principles of the business judgment rule basically consists of the arrangements and legal basis. Indonesia set the business judgment rule principle clearly in Act No 40 of 2007 on Limited Liability Company. On other hand, Singapore does not regulate clearly. Singapore only has jurisprudence, regulation regarding the principle of the business judgment rule in Singapore it is emphasized in good faith or bona fide in Singapore Companies Act. The doctrine of the business judgment rule is emphasized in good faith, which is intended as a precaution for a director to create risks that cannot be accepted by a limited company and prevent fraud or the use of excessive power regulated in the Singapore companies Act.

Understanding of legal entities as rechtpersoon where we see from the point of view of being a country with a civil law legal system. To discuss this research which also intersects with the Anglo Saxon legal system, it can be compared to legal entities in the common law legal system. In common law systems, legal entities are defined as corporations. In the comparison of the understanding of legal entities through some of the above meanings that legal entities according to common law and civil law actually do not have so much difference. Both of them put together that legal entities or legal subjects are separate in which both can be prosecuted and demanded in court. This makes both of them able to enter into an agreement and also legally registered.

This also includes the doctrine of the Business Judgment where this doctrine originates from the common law, and we in Indonesia actually adapt to the doctrine of the Business Judgment rule. The following table is an analysis carried out by the author in comparing the implementation of the principles of business judgment rules in Singapore and Indonesia. Besides having differences, there are similarities from the business juice management rule principles that apply in Indonesia and in Singapore. The similarity is that this principle applies to directors because their duties are to carry out the daily activities of the company. In addition, in this principle, what was seen was the actions of the directors who had indeed tried to benefit the company, which turned out the company was still losing money. This is important because of the two countries indeed the assessment was carried out from the good faith of a director. The principle of the business judgment rule in Singapore and in Indonesia is actually not much different and can be applied. The only difference that is quite prominent is the role of the commissioner. Commissioners are not known in common law countries such as Singapore, so it could direct shareholders carry out supervision.

\section{Reference}

Agrawal, R. (2017). The Legal Overview of Singapore's Corporate Sector. Ct. Uncourt, 4, 15.

Choo, P. K. M. (2001). The Statutory Derivative Action in Singapore-A Critical and Comparative Examination. Bond L. Rev., 13, i.

Gibson, G. (2003). Law for Directors. Sydney: Federation Press.

Goddard, R. (2008). Directors' Duties. Edinburgh L. Rev., 12, 468.

Hinsey IV, J. (1983). Business Judgment and the American Law Institute's Corporate Governance Project: the Rule the Doctrine and the Reality. Geo. Wash. L. Rev., 52, 609. 
Khairandy, R., \& Latif, A. (2009). Limited company: doctrine, laws and regulations, and jurisprudence (Indonesian). Kreasi Total Media.

Langford, R. T. (2011). The Duty of Directors to Act Bona Fide in the Interests of the Company: A Positive Fiduciary Duty? Australia and the UK Compared. Journal of Corporate Law Studies, 11(1), 215-242.

Loke, A. F. (2005). Sending the Right Signals on Corporate Liability for Employee Insider Trading. Sing J. Legal Stud., 137 .

Mohd-Sulaiman, A. N. (2009). Directors' Reliance and Responsibility to Supervise and Auditors' Duty of Care Planassurance PAC Formerly Known as Patrick Lee Pac v Gaelic Inns Pte Ltd. Available at SSRN 1400448.

Pinsler, J. (2004). Expert's Duty to Be Truthful in the Light of the Rules of Court. SAcLJ, $16,407$.

Sealy, L. S. (1989). Bona Fides and Proper Purposes in Corporate Decisions. Monash UL Rev., 15, 265.

Sealy, L. S. (1992). Company-Directors' Unconstitutional Acts. The Cambridge Law Journal, 51(2), $229-231$.

Smart, P. (2000). The company law and division of powers. Hong Kong Lawyer (2000), 29-31.

Solomon, L. D., \& Palmiter, A. R. (1999). Corporations: Examples and explanations. Aspen Publishers.

Stout, L. A. (2001). In praise of procedure: An economic and behavioral defense of Smith v. Van Gorkom and the business judgment rule. Nw. UL Rev., 96, 675 .

Shubhan, M. H. (2019). Charging director of company with personal bankruptcy for company mismanagement. Jurnal Hukum dan Peradilan, 8(3), 353-370.

Tan, C. H. (2004). Company Law. SAL Ann Rev 125.

Tjio, H. (2016). Securities and financial services regulation. SAL Ann. Rev., 639.

Widiyono, T. (2009). Credit Collateral in Financial Engineering: A Guide for Credit and Banking Analysts (Indonesian). Bogor : Ghalia Indonesi

Widjaja, G. (2004). The responsibility of the Board of Directors for bankruptcy (Indonesian). Jakarta: Grafindo Persada

Wilamarta, M. (2007). Application of Good Corporate Governance Principles in Limited Liability Companies (Indonesian). Jakarta: Center for Education and Legal Studies 